(3) IMMERSION TEST-The joints are completely immersed in water at $20^{\circ} \mathrm{C}$. for I 2 hrs., and are then pulled apart, and the breaking strain recorded.

Tests (2) and (3) are intended to throw light on the behavior of an airscrew under the extreme conditions of a tropical climate and high humidity. Tests were also made with moist heat, and on immersion followed by dry heat, but were discontinued. The last named test was found to be too drastic, all glues giving very low results.

The whole procedure outlined above is an arbitrary one, and for this reason it is necessary rigidly to standardize and adhere to the technique of the method, in order to obtain comparable results. When the break occurs in the wood, as frequently happens in the regular test, one can, of course, only say that the glue is stronger than the wood, and record the figure at which the wood breaks.

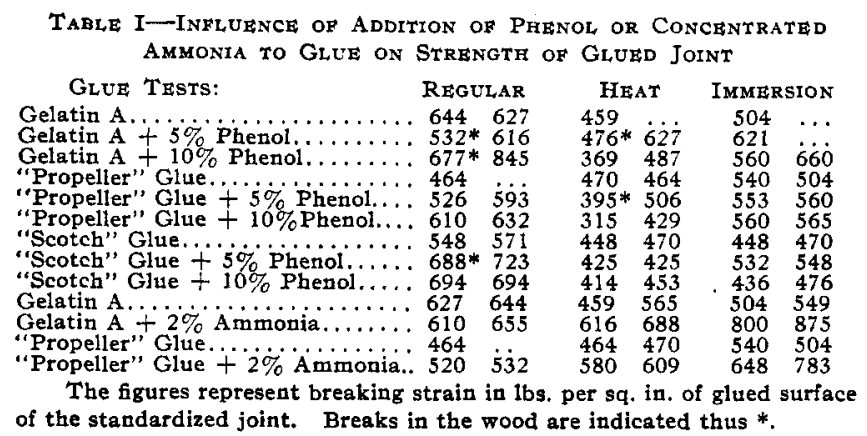

Addition of phenol to the glue improves the regular test. The influence on heat tests and on immersion tests is not marked, but the tendency is to raise them slightly. The addition of 5 per cent phenol to a I : 2 gelatine solution, depressed the setting point of that solution from about 26 to $18^{\circ} \mathrm{C}$., while ro per cent phenol caused the solution to be still viscous at $5^{\circ} \mathrm{C}$. The addition of 5 per cent phenol to glue solutions to be used on aeroplane work is, therefore, to be recommended, both because of its tendency to increase the strength of the joint, and also on account of its action in depressing the setting point.

Ammonia causes the glue to set more rapidly. It was found to have the unexpected effect of raising the figures for heat and immersion tests, while leaving regular tests little affected.

The Germans appear to have used a casein glue on some of their aircraft. An analysis of a Swiss glue of this type showed its composition to be about 66 per cent casein and 23 per cent mineral matter. The latter was composed of soda, silica, lime and alumina. About I per cent of petroleum was present in the powder. This casein glue is prepared for use by rubbing up with cold water. It requires about 3 days for the joint to set, but has the advantage that all the laminae of an airscrew can be glued together at once.

The following test figures were obtained on joints made with the Swiss casein glue:

\begin{tabular}{cccccccc}
\multicolumn{2}{c}{ Regular } & \multicolumn{2}{c}{ Dry Heat } & \multicolumn{2}{c}{ Moist } & Heat & \multicolumn{2}{c}{ Immersion } \\
551 & 655 & 526 & 661 & 448 & 465 & 672 & 862
\end{tabular}

The immersion test is particularly high.
Casein glues are very generally used for cementing together the "veneers" on ply-wood which finds extended use on the fuselage and other parts of the aeroplane. One English firm uses a mixture of casein, lime, and blood, which yields a cement very resistant to water. A three-ply board made with such a cement will withstand an immersion test in water at $50^{\circ} \mathrm{C}$. for 12 hours without any separation of the plies, though the strength of this cement on a "regular" test is inferior to that of a hide glue.

Another firm of ply-wood manufacturers uses lime and casein only, in the proportion approximately of 4 parts by weight of lime to 7 parts by weight of casein. Casein and borax form a good mixture, but are, of course, more expensive than casein and lime. Casein glues cannot be kept more than a few hours after mixing with water, so that a batch when mixed must be completely used, or the residue wasted.

When a new glue is intended for use on airscrews, the tests described above should be supplemented by a practical test of spinning a trial airscrew made with the new glue.

Highland Park, Llanerch, Pa.

\section{A STUDY OF CERTAIN FERMENTS WITH A VIEW TO DETERMINING A METHOD FOR THE DIFFERENTIATION OF PASTEURIZED MILK FROM RAW MILK I. REDUCTASES}

By Richard Edwin Lee and MELViN GUy Mellon Received May 1, 1916 INTRODUCTORY

The enthusiasm and skill with which many of the problems relating to the distribution, composition and action of a class of substances known as enzymes or ferments have been attacked in recent years have contributed much data of importance to the biological chemist and sanitarian.

Some of these ferments are so widely distributed in living tissues of members of both the animal and vegetable kingdoms that it has been suggested by one well-known investigator "that the properties of these substances might almost be turned to account as a general chemical test for vital activity." While this may seem like an exaggeration of their significance and although the precise rôle of these substances in the life of the cell has not yet been determined, it is undoubtedly true that they are concerned in a great many of the most important biochemical processes with which we are familiar. And furthermore, regardless of the fact that very few, if any, of these substances have been isolated in a pure condition, ${ }^{1}$ they have, without doubt, as have other compounds, a definite chemical composition; and through the exercise of definite chemical affinities, they are able to produce alterations in other compounds.

Holding to this view, Traube ${ }^{2}$ formulated his theory of fermentation, for example, upon two distinct chemical propositions: first, that the ferments are defi-

1 It would probably be more accurate to say that we do not know whether a specific enzyme has, or has not been prepared in the pute state.

2 Theorie der Fermentwirkungen, Berlin, 1858; Ueber Aktivirung des Sauerstoffs., 15, 659-675. 
nite chemical compounds elaborated from protein as a result of the combined action of heat, water, and oxygen, and are present not only in the lower organisms but also in the tissues of the higher forms, where they are responsible for biochemical processes; second, that the ferments are powerful reducing agents and oxygen carriers, capable, in the capacity of chemical go-betweens (Vermittler), of effecting the transfer not only of free oxygen to easily oxidizable substances, but also the transfer of combined oxygen from one compound to another.

In accordance with this theory, he was led to divide ferments into three classes: ${ }^{1}$

(a) Verwesungsfermente ${ }^{2}$ - those combined loosely with oxygen, forming unstable compounds which give up their oxygen to other substances less readily oxidized,

(b) Reductionsfermente-those which combine with the oxygen of water, the hydrogen going to effect the reduction of some passive body.

(c) Höchste Fäulnissfermente-those which cause putrefactions in which hydrogen is set free.

Although there is not complete agreement among investigators as to the exact mechanism by which the alterations are effected, there is very general belief that they act catalytically, and, therefore, partake of the nature of ferments; that is, enzymes may be regarded as organic catalysts.

As is well known, they are very unstable, being generally destroyed by an exposure to a temperature outside of relatively narrow limits; and inasmuch as they have optimum, maximum, and minimum temperatures, and thermal death points, they resemble microorganisms.

Usually action ceases at $0^{\circ} \mathrm{C}$; the optimum for most types lies between 30 and $50^{\circ} \mathrm{C}$., they are soon destroyed at temperatures above $70^{\circ} \mathrm{C}$, and almost instantaneously by boiling water. Likewise they are remarkably sensitive to the action of mineral acids such as $\mathrm{HCl}$ and various poisons ${ }^{3}$ such as $\mathrm{HCN}$, $\mathrm{SO}_{2}, \mathrm{HgCl}_{2}, \mathrm{C}_{2} \mathrm{H}_{5} \mathrm{NH}_{2}$ and $\mathrm{CHCl}_{3}$.

It is in virtue, however, of these facts which have been pointed out, viz., the wide distribution of these enzymes in the animal and vegetable kingdoms and their sensitiveness to various physical and chemical agents, that they have become of great importance to the biological chemist and sanitarian, as enabling them by means of specific tests for these enzymes to form correct conclusions regarding the character and condition of certain foodstuffs; $i$. $e$., these tests have enabled the chemist to say whether the food is raw or has been heated.

Among the first of these enzymes to be discovered and to have its properties studied is the group now known as the oxidases. They are among the most widely distributed of all the ferments. These, together with another group known as the reductases,

1 Kastle, Bull. B9, Hygienic Laboratory.

2 Traube in his later writings used the term Oxydationsfermente as preferable to the term Verwesungsfermente. This term is employed to signify those ferments which possess the power of taking up free oxygen and carrying it to other passive substances, thereby accomplishing the oxidation of the latter.

${ }^{3}$ For a more complete list see article by Harris and Creighton, $J$. Biol. Chem., 22 (1915), 535. are of particular interest to us in the consideration of the problem presented in this paper, owing to the presence of the former (oxidases) in milk, and the probable bacterial origin of the reductases.

For a number of years it has been a most interesting question as to whether these enzyme reactions could be made the basis of methods for differentiating old milk from new milk, and pasteurized milk from raw milk. Regardless of the controversy which has arisen, a numbet of investigators have proposed tests in which the reactive properties of these enzymes have been utilized with a view to formulating methods for ascertaining the "sanitary condition" of milk. These investigations seem to be entirely justified when we recall the following well-known facts: (I) Normal fresh milk has the property of decomposing hydrogen peroxide into free oxygen gas and water; (2) ordinary milk possesses the power of decoloring, within certain limits of time, various coloring substances by reduction or removal of oxygen. Although the exact nature of these reactions and the source of the substances in milk influencing them have not been clearly established, there is much evidence which indicates that they are of an enzymic nature.

It is scarcely necessary to point out that there is much uncertainty at the present time as to the accuracy and significance of these proposed tests. There is no question, however, as to the need of them.

Inasmuch as it has often become necessary to pasteurize milk to be sold to the public, because it has not been produced under the required sanitary conditions, the need of a test which will quickly and easily show whether a given sample of milk has been heated or not, is at once obvious. In the effort to meet this want a considerable number of methods have been formulated in the last few years. Unfortunately, most of those proposed are not characterized by exactness or simplicity. However, there seem to be a few methods which have received neither the use nor the study to which they are apparently entitled.

It was this view of the situation which led the authors of this paper to the examination of various methods which have been proposed for the differentiating of raw milk from pasteurized milk with regard to determining their relative accuracy.

The methods which have been proposed may be conveniently divided into two main groups: ${ }^{1}$

(I) Methods based upon changes which the protein in milk undergoes when the latter is heated.

(2) Methods based upon. reactions infuenced by the presence of certain chemical ferments in milk.

An examination of the literature dealing with this subject reveals the fact that only those methods which are included in the second group have proven at all satisfactory. And it will be noted that these are the methods which are based upon the action exerted by the presence of certain enzymes.

In this investigation we have been concerned with but three groups of these chemical ferments: (I) a peroxidase, which causes hydrogen peroxide to react

1 Barthel. "Milk and Dairy Products," p. 97. 


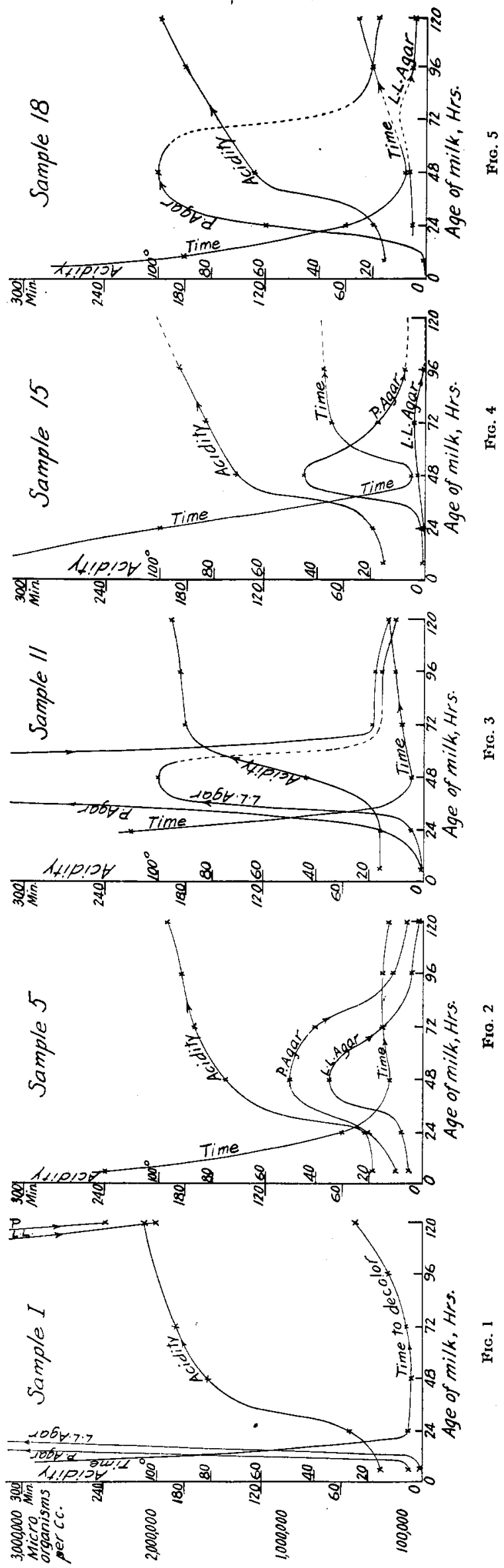

with certain (oxidase) reagents, thereby producing change of colors; (2) a catalase, which decomposes hydrogen peroxide (with the liberation of oxygen) but is incapable of effecting the oxidation of oxidase reagents by means of the peroxide; (3) the reductases, which combine with the oxygen of the water, the liberated hydrogen effecting the reduction of a passive body like methylene blue with attendant decoloration.

Owing to the fact that the peroxidases and catalases are to be taken up in another paper, they will not be considered further at this time as this paper is concerned only with the nature, source, and action of the enzyme which influences the reactions upon which are based the reductase methods.

\section{REDUCTASES IN RELATION TO PROBLEM}

The reductases (Reductionsfermenie) are usually defined as those ferments which combine with the oxygen of water, the hydrogen going to effect the reduction of a passive body like methylene blue.

The reductase test is based upon the fact, first noticed by Duclaux, ${ }^{1}$ that ordinary normal cow's milk has the power of converting certain coloring matters, as indigo-carmine, into the corresponding leuco-compound by reduction. He also showed that this property of milk depends upon the microörganisms which it contains.

Neisser and Wechsberg ${ }^{2}$ proposed the use of methylene blue as a reagent for testing the quality of milk. H. Smidt, ${ }^{3}$ P. Th. Müller, ${ }^{4}$ and $B$ arthe ${ }^{5}$ also worked on this method and came to the conclusion that there existed a distinct parallel between the number of organisms in the milk and the time required, under certain conditions, for a solution of methylene blue to be decolorized. According to Barthel ${ }^{6}$ the reductase test gives approximately the relative number of bacteria in the milk. Van Slyke ${ }^{7}$ seems to agree with this as he maintains that this reducing property appears to depend upon the presence of microörganisms in milk since the larger the number of bacteria, the shorter the time required to produce decoloration.

There seems to be some dispute, however, among other investigators as to the exact origin of the reductase. Konning, ${ }^{8}$ Seligman, ${ }^{9}$ and Grimmer ${ }^{10}$ are of the opinion that the reductases are produced by bacteria. However, Seligman states that possibly some reductases may exist as enzymes in milk. Romer and Sames"1 are opposed to the enzyme nature of reductase, and state that it is produced by the destruction of the cells of the mammary glands during milking, as the first milkings have but slight reducing properties and the last milkings are highly reducing.

Sames ${ }^{12}$ is not only opposed to the enzyme nature of

1 Le Lait, "Éttudes chimiques et microbiologiques," Paris, 1887.

2 Analyst, 26 (1901), 148.

8 Munch. Med. Wochschr., 1900, No. 37.

- Hyg. Rundschau, 14 (1904), 1-137.

4 Arch. Hyg., 56 (1906), 108.

- Z. Nahr. Genussm, 16 (1908), 385; "Milk and Dairy Products," p. 128

7."Modern Methods of Testing Milk and Milk Products," p. 158.

Milchwirtschaft Zentr., 4, 156.

2 Z. Hyg., 58, 1.

10 Milchwirtschaft Zentr., 6, 243.

11 Z. Nahr. Genussm., 20, 1

18 Milchwirtschaft Zenlr., 6, 462. 


\begin{tabular}{|c|c|c|c|c|c|c|c|c|c|c|c|}
\hline & & & & & & & & & & & \\
\hline $\begin{array}{l}\text { Sam- } \\
\text { ple } \\
\text { No. }\end{array}$ & $\begin{array}{l}\text { Age } \\
\text { Hrs. }\end{array}$ & $\begin{array}{c}\text { Degree } \\
\text { of } \\
\text { Acidity }\end{array}$ & $\begin{array}{c}\text { Time to } \\
\text { Decolorize } \\
\text { Methylene Blue }\end{array}$ & $\begin{array}{l}\text { BACTERIAL } \\
\text { Plain Agar }\end{array}$ & $\begin{array}{l}\operatorname{Count}(a) \\
\text { L. L. Agar }\end{array}$ & $\begin{array}{l}\text { Sam- } \\
\text { ple } \\
\text { No. }\end{array}$ & $\begin{array}{l}\text { Age } \\
\text { Hrs. }\end{array}$ & $\begin{array}{c}\text { Degree } \\
\text { of } \\
\text { Acidity }\end{array}$ & $\begin{array}{c}\text { Time to } \\
\text { Decolorize } \\
\text { Methylene Blue }\end{array}$ & $\begin{array}{l}\text { BACTERIAL } \\
\text { Plain Agar }\end{array}$ & $\begin{array}{l}\text { Count }(a) \\
\text { L. L. Agar }\end{array}$ \\
\hline 1 & $\begin{array}{r}4 \\
24 \\
48 \\
72 \\
96 \\
120\end{array}$ & $\begin{array}{l}16.5 \\
27 \\
82 \\
93 \\
100 \\
105\end{array}$ & $\begin{array}{l}\text { No Decol. } \\
10 \text { Min. } \\
7 \text { Min. } \\
12 \text { Min. } \\
25 \text { Min. } \\
50 \text { Min. }\end{array}$ & $\begin{array}{r}90,000 \\
10,000,000 \\
450,000,000 \\
10,000,000 \\
4,000,000 \\
\ldots \ldots\end{array}$ & $\begin{array}{r}30,000 \\
7,000,000 \\
300,000,000 \\
8,000,000 \\
2,000,000 \\
\ldots \ldots \ldots\end{array}$ & 11 & $\begin{array}{r}4 \\
24 \\
48 \\
72 \\
96 \\
120\end{array}$ & $\begin{array}{l}16 \\
16.5 \\
43 \\
95 \\
97 \\
100\end{array}$ & $\begin{array}{l}\text { No Decol. } \\
\text { Several Hrs. } \\
8 \mathrm{Min} . \\
15 \mathrm{Min} . \\
20 \mathrm{Min} . \\
30 \mathrm{Min} .\end{array}$ & $\begin{array}{r}15,000 \\
20,000 \\
5,000,000 \\
370,000 \\
350,000 \\
250,000\end{array}$ & $\begin{array}{r}4,000 \\
10,000 \\
2,000,000 \\
300,000 \\
200,000\end{array}$ \\
\hline 2 & $\begin{array}{r}4 \\
24 \\
48 \\
72 \\
96\end{array}$ & $\begin{array}{l}16 \\
26 \\
43 \\
65\end{array}$ & $\begin{array}{l}\text { No Decol. } \\
30 \text { Min. } \\
25 \text { Min. } \\
15 \text { Min. }\end{array}$ & $\begin{array}{r}500,000 \\
8,000,000 \\
10,000,000 \\
1,000,000\end{array}$ & $\begin{array}{r}400,000 \\
5,000,000 \\
7,000,000 \\
600,000 \\
\ldots \ldots . .\end{array}$ & 12 & $\begin{array}{r}8 \\
24 \\
48 \\
72 \\
96\end{array}$ & $\begin{array}{l}17 \\
18 \\
44 \\
90 \\
97\end{array}$ & $\begin{array}{l}\text { No Decol. } \\
65 \mathrm{Min} . \\
4 \mathrm{Min} . \\
15 \mathrm{Min} . \\
14 \mathrm{Min} .\end{array}$ & $\begin{array}{r}9,000 \\
400,000 \\
1,500,000 \\
500,000 \\
400,000\end{array}$ & $\begin{array}{r}3,000 \\
150,000 \\
1,000,000 \\
350,000 \\
150,000\end{array}$ \\
\hline & 120 & $8 \dot{5}$ & 50 Min. & $1,000,000$ & $1,000,000$ & & 120 & $\ldots$ & $\ldots \ldots \ldots$ & $\ldots \ldots$ & $\ldots \ldots$ \\
\hline 3 & $\begin{array}{r}8 \\
24 \\
48 \\
72\end{array}$ & $\begin{array}{l}19 \\
21 \\
25 \\
\cdots\end{array}$ & $\begin{array}{l}\text { No Decol. } \\
\text { Several Hrs. } \\
\text { Several Hrs. } \\
\text {. . . . . . }\end{array}$ & $\begin{array}{r}150,000 \\
160,000 \\
6,000,000 \\
\ldots \ldots\end{array}$ & $\begin{array}{r}\dddot{40,000} \\
4,000,000 \\
\ldots \ldots\end{array}$ & 13 & $\begin{array}{r}4 \\
24 \\
48 \\
72\end{array}$ & $\begin{array}{l}17 \\
20 \\
64 \\
84\end{array}$ & $\begin{array}{l}\text { No Decol. } \\
40 \mathrm{Min} . \\
10 \mathrm{Min} . \\
18 \mathrm{Min} .\end{array}$ & $\begin{array}{r}15,000 \\
90,000 \\
8,000,000 \\
2,000,000\end{array}$ & $\begin{array}{r}6,000 \\
10,000 \\
3,000,000 \\
1,000,000\end{array}$ \\
\hline & $\begin{array}{r}96 \\
120\end{array}$ & $\begin{array}{r}\ddot{9} \dot{5} \\
103\end{array}$ & $\begin{array}{l}35 \text { Min. } \\
45 \text { Min. }\end{array}$ & $\begin{array}{l}3,000,000 \\
1,000,000\end{array}$ & $\begin{array}{r}2,000,000 \\
800,000\end{array}$ & & $\begin{array}{r}96 \\
120\end{array}$ & $\cdots$ & $\ldots \ldots \cdots$ & $\ldots \ldots$ & $\ldots \ldots$ \\
\hline 4 & $\begin{array}{r}3 \\
24 \\
48\end{array}$ & $\begin{array}{l}15 \\
21\end{array}$ & $\begin{array}{l}\text { No Decol. } \\
28 \text { Min. }\end{array}$ & $\begin{array}{l}20,000 \\
80,000\end{array}$ & $\begin{array}{l}10,000 \\
50,000\end{array}$ & 14 & $\begin{array}{r}8 \\
24 \\
48\end{array}$ & $\begin{array}{l}17 \\
18 \\
61\end{array}$ & $\begin{array}{l}\text { No Decol. } \\
25 \text { Min. } \\
4 \text { Min. }\end{array}$ & $\begin{array}{r}13,000 \\
1,500,000 \\
5,000,000\end{array}$ & $\begin{array}{r}1,700 \\
30,000 \\
60,000\end{array}$ \\
\hline & $\begin{array}{r}40 \\
72 \\
96 \\
120\end{array}$ & $\begin{array}{l}78 \\
87 \\
95\end{array}$ & $\begin{array}{l}35 \text { Min. } \\
55 \text { Min. } \\
75 \text { Min. }\end{array}$ & $\begin{array}{r}2,000,000 \\
2,000,000 \\
100,000\end{array}$ & $\begin{array}{r}1,000,000 \\
1,000,000 \\
60,000\end{array}$ & & $\begin{array}{r}72 \\
96 \\
120\end{array}$ & $\begin{array}{l}90 \\
93 \\
96\end{array}$ & $\begin{array}{l}30 \mathrm{Min} . \\
60 \mathrm{Min} . \\
60 \mathrm{Min} .\end{array}$ & $\begin{array}{r}1,500,000 \\
50,000 \\
30,000\end{array}$ & $\ldots$ \\
\hline 5 & $\begin{array}{r}4 \\
24 \\
48 \\
72 \\
96 \\
120\end{array}$ & $\begin{array}{l}18 \\
22 \\
76 \\
87 \\
92 \\
97\end{array}$ & $\begin{array}{l}4 \text { Hrs. } \\
1 \text { Hr. } \\
25 \text { Min. } \\
30 \text { Min. } \\
30 \text { Min. } \\
35 \text { Min. }\end{array}$ & $\begin{array}{r}200,000 \\
400,000 \\
1,000,000 \\
800,000 \\
220,000 \\
180,000\end{array}$ & $\begin{array}{r}100,000 \\
150,000 \\
700,000 \\
300,000 \\
75,000 \\
50,000\end{array}$ & 15 & $\begin{array}{r}8 \\
24 \\
48 \\
72 \\
96 \\
120\end{array}$ & $\begin{array}{r}15 \\
19 \\
72 \\
83 \\
93 \\
\cdots\end{array}$ & $\begin{array}{c}\text { Slightly, } 3 \text { Hrs. } \\
\text { Partly, } 3 \text { Hrs. } \\
10 \text { Min. } \\
70 \text { Min. } \\
75 \text { Min. } \\
\text {. . . . . . . }\end{array}$ & $\begin{array}{r}8,000 \\
20,000 \\
900,000 \\
350,000 \\
150,000 \\
\ldots \ldots \ldots\end{array}$ & $\begin{array}{r}r 3,000 \\
50,000 \\
70,000 \\
10,000 \\
\ldots \ldots\end{array}$ \\
\hline 6 & $\begin{array}{r}8 \\
24 \\
48 \\
72 \\
96\end{array}$ & $\begin{array}{l}19 \\
20 \\
72 \\
88 \\
99\end{array}$ & $\begin{array}{l}5 \text { Hrs. } \\
4 \text { Hrs. } \\
10 \text { Min. } \\
18 \text { Min. } \\
60 \text { Min. }\end{array}$ & $\begin{array}{r}20,000 \\
160,000 \\
4,000,000 \\
800,000 \\
600,000\end{array}$ & $\begin{array}{r}15,000 \\
40,000 \\
750,000 \\
100,000 \\
\ldots \ldots\end{array}$ & 16 & $\begin{array}{l}4 \\
24 \\
48 \\
72 \\
96\end{array}$ & $\begin{array}{l}19 \\
22 \\
86 \\
96\end{array}$ & $\begin{array}{l}\text { Partly, } 3 \mathrm{Hrs.} \\
25 \mathrm{Min} . \\
20 \mathrm{Min} . \\
30 \mathrm{Min} . \\
\ldots . . .\end{array}$ & $\begin{array}{r}8,000 \\
20,000 \\
100,000 \\
20,000 \\
\ldots \ldots\end{array}$ & $\begin{array}{r}1,000 \\
3,000 \\
20,000 \\
16,000 \\
\ldots \ldots\end{array}$ \\
\hline & 120 & $\cdots$ & slightly & $\ldots \ldots$ & $\ldots \ldots$ & & $\begin{array}{l}90 \\
120\end{array}$ & $i 02$ & $\dot{35}$ Min. & 10,000 & 3,000 \\
\hline 7 & $\begin{array}{r}4 \\
24 \\
48 \\
72 \\
06\end{array}$ & $\begin{array}{l}19 \\
22 \\
74 \\
79\end{array}$ & $\begin{array}{l}6 \mathrm{Hrs} \text {. } \\
2 \mathrm{Hrs} \text {. } \\
6 \mathrm{Min} \text {. } \\
40 \mathrm{Min} .\end{array}$ & $\begin{array}{r}20,000 \\
100,000,000 \\
1,000,000 \\
750,000\end{array}$ & $\begin{array}{r}10,000 \\
75,000,000 \\
50,000 \\
40,000\end{array}$ & 17 & $\begin{array}{r}4 \\
24 \\
48 \\
72 \\
96\end{array}$ & $\begin{array}{l}19.5 \\
23 \\
86 \\
96\end{array}$ & $\begin{array}{l}\text { Partly, } 3 \mathrm{Hrs} . \\
20 \mathrm{Min} . \\
18 \mathrm{Min} . \\
15 \mathrm{Min} .\end{array}$ & $\begin{array}{r}10,000 \\
100,000 \\
130,000 \\
100,000\end{array}$ & $\begin{array}{r}1,000 \\
3,500 \\
70,000 \\
55,000\end{array}$ \\
\hline & $\begin{array}{r}96 \\
120\end{array}$ & $\ddot{9}$ & $30 \ddot{\mathrm{Min}}$ & $\dot{5} 00,000 \dot{0}$ & $\ddot{6} \ddot{0}, \dot{0} 0 \dot{0}$ & & 120 & $i \ddot{0} \dot{0}$ & 45 Min. & $i 0,000$ & $\ddot{2}, \dot{0} 0 \dot{0}$ \\
\hline 8 & $\begin{array}{r}4 \\
24 \\
48\end{array}$ & $\begin{array}{l}16 \\
17 \\
75\end{array}$ & $\begin{array}{l}\text { No Decol. } \\
35 \text { Min. } \\
10 \mathrm{Min} \text {. }\end{array}$ & $\begin{array}{r}10,000 \\
600,000 \\
10,000,000\end{array}$ & $\begin{array}{r}00,000 \\
4,000 \\
150,000 \\
500,000\end{array}$ & 18 & $\begin{array}{r}8 \\
24 \\
48 \\
72\end{array}$ & $\begin{array}{l}16 \\
19 \\
64\end{array}$ & $\begin{array}{l}\text { Slightly, } 150 \text { Min. } \\
60 \mathrm{Min} . \\
15 \mathrm{Min} .\end{array}$ & $\begin{array}{r}5,000 \\
1,200,000 \\
2,000,000\end{array}$ & $\begin{array}{l}\dot{10} \ddot{0}, \dot{0} \dot{0} \dot{0} \\
120,000\end{array}$ \\
\hline & $\begin{array}{r}72 \\
96 \\
120\end{array}$ & $\begin{array}{l}90 \\
96\end{array}$ & $\begin{array}{l}\text { is Min. } \\
12 \mathrm{Min.}\end{array}$ & $\begin{array}{l}1,000,000 \\
1,000,000\end{array}$ & $\begin{array}{l}400,000 \\
500,000\end{array}$ & & $\begin{array}{r}96 \\
120\end{array}$ & $\begin{array}{l}\dot{8} 9 \\
98\end{array}$ & $\begin{array}{l}40 \text { Min. } \\
50 \text { Min. }\end{array}$ & $\begin{array}{l}400,000 \\
350,000\end{array}$ & $\begin{array}{r}100,000 \\
80,000\end{array}$ \\
\hline 9 & $\begin{array}{r}4 \\
24 \\
48\end{array}$ & $\begin{array}{l}15 \\
18 \\
\cdots\end{array}$ & $\begin{array}{l}150 \mathrm{Min} . \\
90 \mathrm{Min} . \\
\ldots \ldots \ldots\end{array}$ & $\begin{array}{r}10,000 \\
100,000\end{array}$ & $\because 0,000$ & 19 & $\begin{array}{r}8 \\
24 \\
48\end{array}$ & $\begin{array}{l}16.5 \\
17 \\
82\end{array}$ & $\begin{array}{l}150 \mathrm{Min} . \\
120 \mathrm{Min} . \\
40 \mathrm{Min} .\end{array}$ & $\begin{array}{r}5,000 \\
75,000 \\
100,000\end{array}$ & $\begin{array}{l}20,000 \\
25,000\end{array}$ \\
\hline & $\begin{array}{r}40 \\
72 \\
96 \\
120\end{array}$ & $\begin{array}{l}76 \\
88 \\
90\end{array}$ & $\begin{array}{l}\text { io Min. } \\
30 \mathrm{Min} . \\
35 \mathrm{Min} .\end{array}$ & $\begin{array}{r}1,000,000 \\
200,000 \\
120,000\end{array}$ & $\begin{array}{l}80,000 \\
60,000 \\
50,000\end{array}$ & & $\begin{array}{r}72 \\
96 \\
120\end{array}$ & $\begin{array}{r}\dot{9} \dot{5} \\
103\end{array}$ & $\begin{array}{l}60 \text { Min. } \\
60 \text { Min. }\end{array}$ & $\begin{array}{l}80,000 \\
30,000\end{array}$ & $\begin{array}{l}50,000 \\
10,000\end{array}$ \\
\hline 10 & $\begin{array}{r}8 \\
24\end{array}$ & $\begin{array}{r}19 \\
. .9\end{array}$ & No Decol. & 10,000 & $\ldots \ldots$ & 20 & $\begin{array}{r}4 \\
24\end{array}$ & $\begin{array}{l}17 \\
33\end{array}$ & $\begin{array}{l}\text { Slightly, } 3 \mathrm{Hrs} \\
15 \mathrm{Min} .\end{array}$ & $\begin{array}{r}30,000 \\
400,000\end{array}$ & $\begin{array}{r}8,000 \\
40,000\end{array}$ \\
\hline & $\begin{array}{r}48 \\
72 \\
96 \\
120\end{array}$ & $\begin{array}{r}59 \\
95 \\
102 \\
107\end{array}$ & $\begin{array}{l}4 \mathrm{Min} . \\
10 \mathrm{Min} . \\
14 \mathrm{Min} . \\
18 \mathrm{Min} .\end{array}$ & $\begin{array}{r}1,350,000 \\
1,300,000 \\
500,000 \\
300,000\end{array}$ & $\begin{array}{r}100,000 \\
80,000 \\
80,000 \\
10,000\end{array}$ & & $\begin{array}{r}48 \\
72 \\
96 \\
120\end{array}$ & $\begin{array}{r}100 \\
107 \\
98\end{array}$ & $\begin{array}{l}\text { is Min. } \\
30 \text { Min. } \\
60 \text { Min. }\end{array}$ & $\begin{array}{r}140,000 \\
100,000 \\
20,000\end{array}$ & $\begin{array}{l}20,000 \\
10,000 \\
\ldots \ldots\end{array}$ \\
\hline
\end{tabular}
all bacterial

reductase but insists that Seligman's assumption that the reduction is due to bacteria is too far-reaching. Salus ${ }^{1}$ believes that reductase is a product of cell transformation. Oppenheimer ${ }^{2}$ is of the opinion that the reductase is in no way related to the bacteria and that it is merely difficult to distinguish from bacterial reductases.

However, on the basis of the probable bacterial origin of reductase, there have been two tests proposed for its detection:

(I) Schardinger's $M$. Reductase Test, ${ }^{3}$ which is carried out by adding I cc. of Schardinger's reagent M. (viz., 5 cc. of a saturated alcoholic solution of methylene blue and I95 cc. of water) to $20 \mathrm{cc}$. of milk in a test tube and placing it in a water bath at 45 to $50^{\circ} \mathrm{C}$. With this reagent a number of hours is required to produce decoloration.

(2) Schardinger's F. M. Reductase Test, ${ }^{4}$ which is carried out by adding I cc. of Schardinger's F. M.

1 Arch. Hyg., 75, 371.

2 Arb. Kgl. Inst. Experim. Therap. zu Frankfort $a / M, 1908,75$.

- Z. Nahr. Genussm., 2 (1906), 377.

- This Journal, 5 (1913), 922-927. reagent (viz., 5 cc. of a saturated alcoholic solution of methylene blue, $5 \mathrm{cc}$. of 40 per cent formaldehyde, and $190 \mathrm{cc}$. of water) to $20 \mathrm{cc}$. of milk in a test tube, placing it in a water bath at 45 to $50^{\circ} \mathrm{C}$., and covering the contents of the tube with a layer of liquid petroleum to prevent the access of air. The formaldehyde serves to produce an acceleration in the time of reduction. Lythgoe $^{1}$ states that raw milk will decolor this reagent in less than $20 \mathrm{~min}$. and pasteurized milk will take a longer time.

The reaction depends upon the supposed presence of a specific enzyme in milk called aldehyde-reductase, which is more or less quickly destroyed at a temperature above $70^{\circ} \mathrm{C}$; when in milk heated above $80^{\circ} \mathrm{C}$., its destruction is complete. ${ }^{2}$ Barthel $^{3}$ states that the enzyme is destroyed more or less quickly at temperatures above $70^{\circ} \mathrm{C}$; and that milk heated to $80^{\circ} \mathrm{C}$. does not discharge the color at all; or milk heated to $75^{\circ} \mathrm{C}$. for a few minutes or pasteurized for I 5 minutes at $70^{\circ} \mathrm{C}$., discharges the color in 30 minutes.

1 This Journal, 6 (1913), 922-927. p. 163.

2 Van Slyke, "Modern Methods of Testing Milk and Milk Products," " Milk and Dairy Products," p. 128 


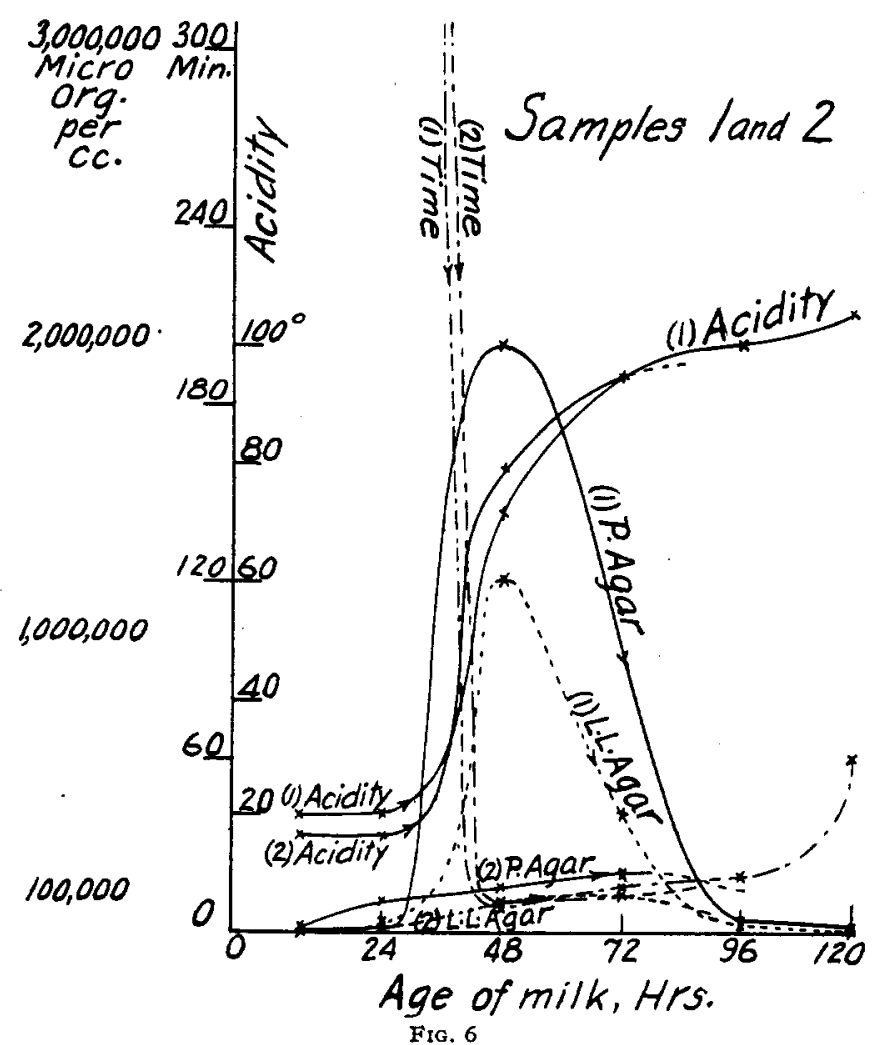

By means of these reagents it is possible, according to Lythgoe, ${ }^{1}$ to get a good idea of the temperature to which the milk has been heated, and also how long it has been heated, since heating the milk destroys the enzyme. Thus, he maintains, this method affords a very good means of distinguishing between raw and pasteurized milk.

As stated previously, there seems to be a difference of opinion as to the origin of the reductase; likewise investigators are far from any agreement regarding any relationship which may exist between the time of methylene blue reduction and the number of bacteria present. Angelici2 states that there is absolutely no parallelism between the two. Fred, ${ }^{3}$ however, holds to the view that most, but not all, milk bacteria reduce methylene blue; and that milk reducing methylene blue in from 15 minutes to an hour contains from $I_{5}$ to 50 millions of bacteria per cc., and milk requiring 7 hours or more contains less than one million bacteria per ćc.

Barthel ${ }^{4}$ states that fresh milk containing 10,000 bacteria per cc. decolorized the methylene blue solution in I I hrs.; and the same milk four days old containing I 7 millions of bacteria per cc. decolored the solution in $14 \mathrm{~min}$. He further maintains that when the reduction takes place in less than one hour, the milk has more than Io million bacteria per cc., and when the time required is from $\mathrm{I}$ to $3 \mathrm{hrs}$, the number of bacteria present is from 4 to ro millions per cc. As a conclusion he asserts that when the reduction requires less

1 This Journal, 5 (1913), 922-927.

2 Clin. Vat., 34, 388.

3 Centr. Bakt. Parasitenk., II Abt., 35, 491.

- Z, Nahr. Genussm., 15, 385.

Ibid., 21, 513 .

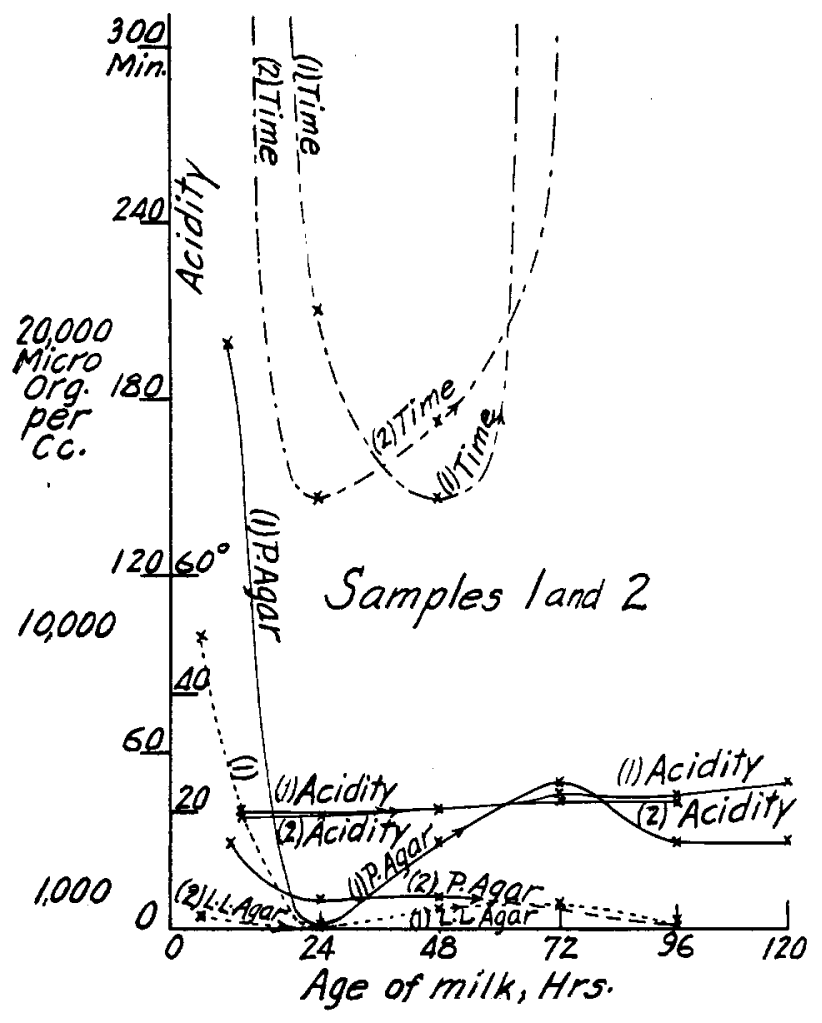

Frg. 7

than I hour, the milk is bacterially too impure for food; and that good commercial milk should require not less than 3 hours for decoloration.

As a result of the foregoing discussion, therefore, we may conclude that there exists a considerable difference of opinion: ( $\mathrm{I}$ ) as to whether the reductase is of bacterial origin or of animal metabolism; and (2) as to the relationship existing between the time of methylene blue reduction and the number of bacteria present.

\section{EXPERIMENTAL}

The following experimental work was carried on with a view to determining by means of the Schardinger F. M. test:

I-The relationship existing between the number of bacteria and the time required to decolorize the methylene blue solution.

2-The influence of time and temperature of pasteurization on milk in its relation to Schardinger's reagent, F. M.

RELATIONSHIP BETWEEN NUMBER OF BACTERIA AND TIME REQUIRED TO DECOLORIZE METHYLENE BLUE

Twenty samples of milk were tested as follows: (I) the acidity was determined by titration with $N /$ Io $\mathrm{NaOH}$, o.I cc. of the solution being equivalent to $\mathrm{I}^{\circ}$ of acidity; (2) the time required to decolor methylene blue solution was observed; (3) bacterial counts were made at the time of each test both on plain agar and on lactose litmus agar. Each sample was tested daily for a period of five days, during which time the milk was allowed to remain at the temperature of the laboratory. The results of this work appear in Table $I$.

The full significance of this data becomes more easily 
apparent when it is presented graphically. In Figs. I to 5 , graphs have been drawn of 5 of the representative samples of the above series, using separate curves to show the increase in degrees of acidity, the time of decoloration of methylene blue, the plain agar bacterial count, and the lactose litmus agar bacterial count. The dotted portion of the curves indicates the probable course covering the period during which no tests were made, as, for example, on Sundays.

The age of the milk in hours is plotted as abscissas. There are three sets of ordinates: first, the column on the left by which both the plain agar and the lactose litmus agar counts are plotted; second, the middle column expressed in minutes, by which the time of decoloration is plotted; and third, the column on the right expressed in degrees, by which the degree of acidity is plotted. This gives four curves for each sample.

From the data presented in the preceding table and by means of graphs the following conclusions have been formulated:

(I) An increase of acidity occurs with increase of age. In the periods examined this increase was greatest in the majority of cases in the period between 24 and $48 \mathrm{hrs}$.

(2) Normal fresh milk of good quality does not reduce Schardinger's F. M. reagent in less than 20 min.-the shortest time observed being much longer. When the decoloration was effected in Io min. or less time, the milk was found to contain at least $I, 000,000$ microörganisms per cc.

(3) Up to a certain point an increase in the number of bacteria in a given sample is accompanied by a corresponding decrease in the time required by it to decolor the reagent. At this point the maximum bacterial count and the minimum time required for decoloration coincide.

This relationship seems to point to the conclusion that the reductase is of bacterial origin. The tables will show, however, if data for different samples are compared, that no absolute parallelism exists between the time required for decoloring the reagent and the number of bacteria present. This is in agreement with results obtained by Angelici. ${ }^{1}$

(4) As the acidity increases beyond this point of coincidence the number of bacteria decreases and the time required for decoloration increases.

(5) The final decrease in the number of bacteria and the increase in the time of decoloration are probably due to the production of acid by acid-forming bacteria, the acid thus produced probably tending to remove the effect produced by the aldehyde-reductase and to make the medium unfit for the further growth of certain bacteria.

The foregoing conclusions are in accord with the data obtained in this laboratory over two years ago by F. W. Fabian ${ }^{2}$ working on a similar problem.

In this connection it is noted that it is a matter of record that Lythgoe $^{3}$ found that normal fresh milk reduced Schardinger's F. M. reagent in less than 20 min. The authors are unable at this time to account

1 Clin. Vat., 34, 388. author.

2 Working in this laboratory in 1912 in collaboration with the senior

${ }^{3}$ This Journal, 5 (1913), 922-927. for this discrepancy in the time element, unless it can be attributed to a difference in the standard of milk which is to be regarded as "normal."

Table II is quoted from the report of Mr. Fabian's work to which reference has just been made.

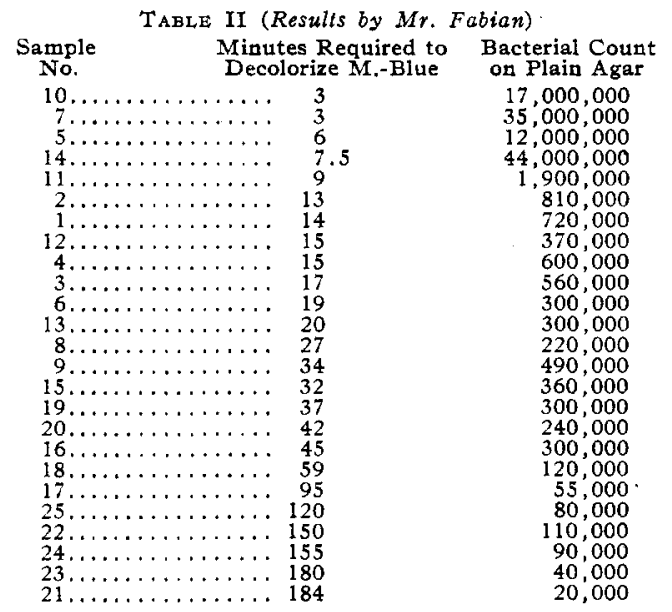

Twenty-five different samples of raw milk were tested with Schardinger's reagent, F. M. A bacterial count was also made of each sample.

\section{EFFECT OF TIME AND TEMPERATLRE OF PASTEURIZA- TION ON MILK IN ITS RELATION TO SCHAR- DINGER'S REAGENT}

Four separate portions of each of three different samples of milk were heated gradually-a rise of $2^{\circ} \mathrm{C}$. per min.-in a water bath to $60,65,70$ and $75^{\circ} \mathrm{C}$, and then maintained at these respective temperatures for $30 \mathrm{~min}$. Portions were removed every Io min. and tested with the reagent. Bacterial counts were made of each sample tested at the various intervals of time. Milk Io hrs. old was used, as fresh milk 4 hrs. old produced no decoloration of the reagent. The results obtained are given in Table III.

\begin{tabular}{|c|c|c|c|c|c|}
\hline \multirow{3}{*}{$\begin{array}{c}\text { Sam- } \\
\text { ple } \\
\text { No. }\end{array}$} & \multicolumn{5}{|c|}{ TABLE III } \\
\hline & \multicolumn{2}{|c|}{ PASTEURIZATION } & Time Required & \multirow{2}{*}{\multicolumn{2}{|c|}{$\begin{array}{c}\text { BACTERIAL COUNT } \\
\text { ON AGAR }\end{array}$}} \\
\hline & Temp. & $\begin{array}{l}\text { Time } \\
\text { Min. }\end{array}$ & $\begin{array}{l}\text { to Decolorize } \\
\text { Min. }\end{array}$ & & \\
\hline & 60 & 0 & 30 & 40000 & 12000 \\
\hline & & 10 & 30 & $\begin{array}{l}40,000 \\
12,000\end{array}$ & $\begin{array}{r}12,000 \\
6,500\end{array}$ \\
\hline & & 20 & 95 & 6,000 & 3,500 \\
\hline & & 30 & 150 & 2,000 & 1,200 \\
\hline & 65 & 0 & 60 & 40,000 & 11,000 \\
\hline & & 10 & 100 & 10,000 & 4,000 \\
\hline & & 20 & 120 & 400 & None \\
\hline & & 30 & 160 & 200 & None \\
\hline & 70 & 0 & 65 & 35,000 & 11,000 \\
\hline & & 10 & No decolor. & 200 & None \\
\hline & & 20 & No decolor. & None & None \\
\hline & & 30 & No decolor. & None & None \\
\hline & 75 & 0 & 65 & 36,000 & 10,000 \\
\hline & & 10 & No decolor. & 300 & None \\
\hline & & 20 & No decolor. & None & None \\
\hline & & 30 & No decolor. & None & None \\
\hline 2. & 60 & 0 & 28 & 70,000 & 25,000 \\
\hline & & 10 & 65 & 19,000 & 9.000 \\
\hline & & 20 & 87 & 8,000 & $\begin{array}{l}5,000 \\
3,000\end{array}$ \\
\hline & 65 & 0 & $\begin{array}{l}135 \\
55\end{array}$ & $\begin{array}{l}4,000 \\
65,000\end{array}$ & 31,000 \\
\hline & & 10 & $\begin{array}{l}30 \\
90\end{array}$ & 15,000 & 8,000 \\
\hline & & 20 & 120 & 1,000 & 200 \\
\hline & & 30 & 155 & & None \\
\hline & 70 & 0 & 56 & 44,000 & 23,000 \\
\hline & & 10 & No decolor. & 700 & 35 \\
\hline & & 20 & No decolor. & None & None \\
\hline & -5 & 30 & No decolor. & None & None \\
\hline & 15 & 10 & No decolor. & $\begin{array}{r}30,000 \\
200\end{array}$ & $\begin{array}{l}18,000 \\
\text { Noze }\end{array}$ \\
\hline & & 20 & No decolor. & None & None \\
\hline & & 30 & No decolor. & None & None \\
\hline 3. & 75 & 0 & 48 & 35,000 & 21,000 \\
\hline & & 10 & No decolor. & 150 & None \\
\hline
\end{tabular}

These data indicate that both the temperature and the duration of the pasteurization process affect milk 
with reference to the time required by the latter to decolorize methylene blue. In general, as either factor is increased the time required for decoloration is increased. Furthermore, the authors found as the result of a larger number of tests than are recorded here that milk heated to a temperature of $70^{\circ} \mathrm{C}$. for ro min. failed to decolor the reagent in several hours. In this latter respect the behavior of samples of milk pasteurized under the stated conditions was identical with that of freshly drawn milk of good grade.

Mr. Fabian found that milk pasteurized at $80^{\circ} \mathrm{C}$. for I min. behaved towards the reagent in the same manner as milk pasteurized at $75^{\circ} \mathrm{C}$. for $3 \mathrm{~min}$. or at $70^{\circ} \mathrm{C}$. for Io min., and that in no case was the reagent decolored in several hours. Table IV is quoted from Mr. Fabian's report. Samples of raw milk, eight hours old, were used in making the tests indicated.

$$
\text { TABLE IV (Results by Mr. Fabian) }
$$

$\begin{array}{cccc}\begin{array}{c}\text { Temp. }\left({ }^{\circ} \mathrm{C}\right) \text { of } \\ \text { Pasteurization }\end{array} & \begin{array}{c}\text { Duration of } \\ \text { Pasteurization }\end{array} & \begin{array}{c}\text { Minutes Required } \\ \text { to Decolorize } \\ \text { Duplicates }\end{array} \\ 60 & 20 & 20 & 19 \\ 60 & 15 & 16 & 18 \\ 60 & 10 & 13 & 17 \\ 60 & 5 & 7 & 7 \\ 60 & 0 & + & + \\ 70 & 20 & 40 & +4 \\ & 10 & 3 & 4 \\ 75 & 5 & + & + \\ & 0 & 4 & + \\ 80 & 10 & + & + \\ & 5 & + & + \\ & 5 & + & + \\ & 3 & 3 & + \\ & 2 & & +\end{array}$

FURTHER EVIDENCE AS TO THE ORIGIN OF REDUCTASE

With a view to obtaining more evidence in regard to the origin of reductase in milk, 5 samples of the latter were pasteurized at $70^{\circ} \mathrm{C}$. for ro min. and then set aside. The samples, in the usual paper-diskcovered bottles, were allowed to "age" at the usual laboratory temperatures. They were tested at intervals of $24 \mathrm{hrs}$. with the Schardinger reagent and bacterial counts made.

The data obtained by testing the first two samples are presented graphically in Fig. 6.

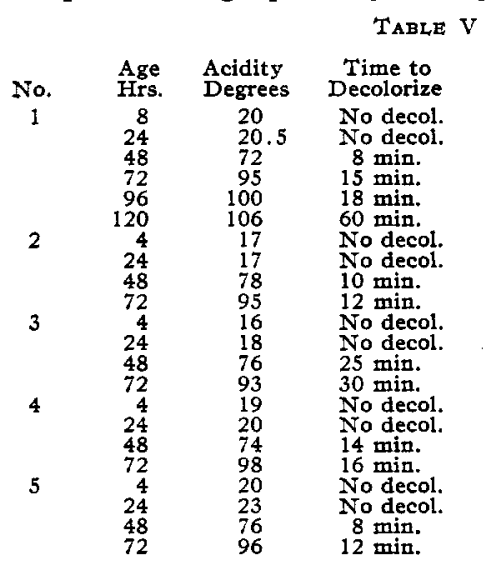

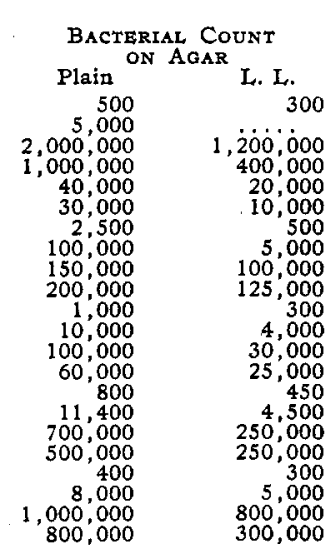

The experiments reported in Table $\mathrm{V}$ yielded results which indicate that milk pasteurized at $70^{\circ} \mathrm{C}$. for ro min. will not decolor methylene blue solution at the expiration of $24 \mathrm{hrs}$. but will after being allowed to stand for $48 \mathrm{hrs}$. This points to the conclusion that reductase is not only destroyed by the pasteurization process but that it is of bacterial origin, the presumption being that no decoloration of the reagent takes place until the bacteria have again multiplied sufficiently.

Mr. Fabian in his work for a similar purpose collected a number of samples of raw milk and after making the bacterial count of each subjected them to a similar set of tests, with the results given in Table VI.

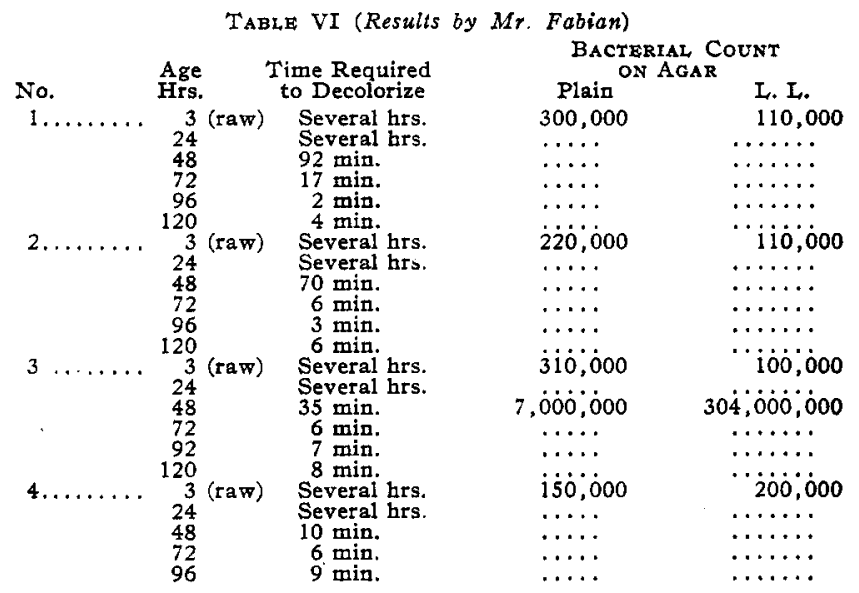

The conclusions to be made here are obviously the same as those formulated in the preceding paragraph.

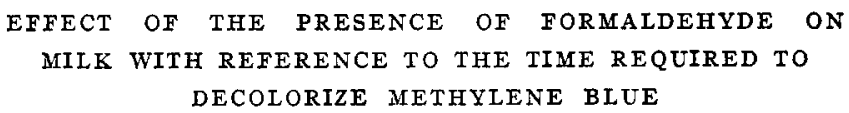

The following work was undertaken in order to ascertain if a so-called "preservative" like formaldehyde influences the action of milk in its relation to the Schardinger reagent. Five different samples of milk, each 8 hours old, were examined as follows: Each sample was tested as regards its acidity, time required to decolor the reagent, and bacterial count; then each sample was treated with formaldehyde $(0.5 \mathrm{cc}$. per pint of milk) and the enumerated tests repeated at intervals of 24 hours. The results are given in Table VII.

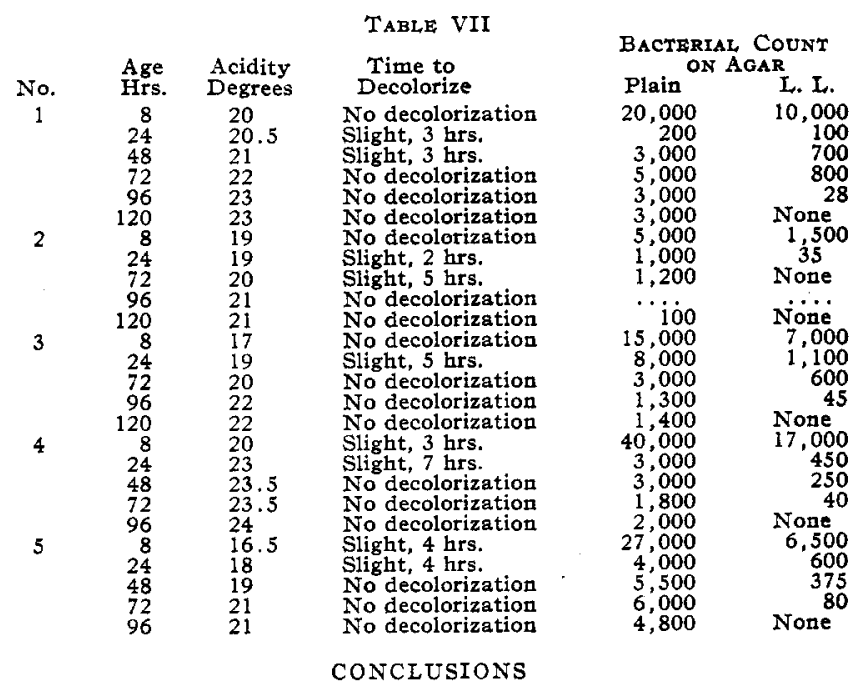

The relationships indicated, if not proved, by this rather limited series of experiments are extremely interesting. For example: 
(I) The germicidal properties of formaldehyde in relation to microörganisms found in milk are shown in a general way.

(2) Unless it be proven that reductase is formed within the milk by purely chemical changes, this series, considered in relation to the foregoing series of tests, points to the conclusion that reductase is of bacterial origin, as the time required for decoloring the reagent was not reduced by allowing the milk to "age," owing presumably to the fact that bacterial growth in the samples of milk was inhibited by the formaldehyde.

(3) The partial decoloration which occurred at first was probably effected by the reductase present in the milk before the formaldehyde was added. The final loss of power of these same samples to effect the same reaction suggests that the formaldehyde may interact with the reductase or counteract its influence in some way. The fact that both of these substances are strong reducing agents does not tend to render the problem more easy of solution.

Since the completion of this work the report of the investigation of Harris and Creighton ${ }^{1}$ on the influence of certain poisons on reductase has appeared. Although the list of poisons reported by them as either destroying the reductase or retarding its action does not include formaldehyde, the latter may act in a similar manner. This, however, will be a matter for future investigation.

\section{GENERAL SUMMARY}

I-A brief outline has been made of the classification, distribution and reactions of certain enzymes; the possibility of making their sensitiveness to various physical and chemical agents the basis of methods for determining the sanitary condition of certain foodstuffs has been considered.

II-A survey has been made of the work done concerning the source, nature and action of reductase in its relation to certain methods which have been proposed for the differentiation of pasteurized milk from raw milk.

III-The experimental investigation undertaken by the authors of this paper has been described. As the result of this work certain conclusions have been formulated. They are as follows:

(I) Methylene blue as it occurs in Schardinger's reagent, F. M., is not decolored by:

(a) Normal fresh milk in less than 20 min. When decoloration was effected in Io minutes or less time the milk was found to contain $I, 000,000$ or more, microorganisms per cc.

(b) Milk pasteurized at $70^{\circ} \mathrm{C}$. for to min. unless approximately $48 \mathrm{hrs}$. have elapsed since the milk was pasteurized; or until the bacteria have had time to multiply sufficiently.

(c) Old milk in which the "preservative," formaldehyde, has inhibited the growth of bacteria.

(2) Schardinger's reagent, F. M., is as a rule de-

1 Harris and Creighton, J. Biol. Chem., 22 (1915), 535. colored by normal milk allowed to "age" under ordinary conditions of temperature for 24 to $48 \mathrm{hrs}$.

(3) Pasteurization increases the time required for the decoloration of the reagent.

(4) In general, no proportionality exists between the time required for the decoloration of the reagent and the number of bacteria in milk. In a given sample, however, a general relation seems to exist between the two up to a given point of acidity.

(5) Inasmuch as there is no absolute parallelism between number of bacteria present in milk and the time required to decolor the reagent but that the relationship seems to exist in a given sample of milk, it would indicate that reductase is of bacterial origin but that not all bacteria found in milk produce this enzyme. (This latter conclusion is in accord with the views of Fred. ${ }^{1}$ )

(6) It seems probable that formaldehyde either gradually retards the action of the reductase or destroys it. This is a matter, however, for more careful investigation in the future.

It will be noted that although the conclusions formulated in this paper are not in accord with the entire body of conclusions of any previous worker in this field, yet many of them are in close agreement with certain conclusions of a number of investigators.

HYGIENIC LABORATORY

CarNegie Hali of Chemistry

Allegheny College, Meadvilie, Pa.

\section{A STUDY OF THE VOLUMETRIC OR PEMBERTON METHOD FOR DETERMINING PHOSPHORIC ACID, WITH SOME EXPERIMENTS SHOWING THE INFLUENCE OF TEMPERATURE AND THE SULFURIC ACID RADICAL ON RESULTS \\ By Philip McG. SHUEY Received October 20, 1916}

There has been a great deal written and said of the volumetric method for determining phosphoric acid, but still many chemists have trouble in its use and manipulation. It has been found by most workers who employ this method that a number of years of careful and patient experience is necessary to master it, and owing to the length of time necessary to acquire this, many chemists have discarded it altogether. The writer has had more than ro years of practical and constant experience in determining phosphoric acid by this method, both with a large fertilizer concern, and in the phosphate fields of Florida, and possibly some points already mentioned can be emphasized in this paper.

On account of the extreme delicacy of the method, and in order to show how it may be rendered accurate and reliable, it might be of interest to include some experiments showing some of the principal causes that bring about disturbances in results. The problem is most interesting, and while no pretense is made that this article will cover the entire field, it is hoped that it will at least serve the purpose of aiding

i Cenir. Bakt. Parasitenke, II Abt, 35, 491.

2 Presented at 53rd Meeting of American Chemical Society, New York City, September 25 to $30,1916$. 